\title{
Board Gender Diversity and Earnings Management: Evidence from China
}

\begin{abstract}
Yihao $\mathrm{Li}^{1, *}$
${ }^{1}$ Wuhan University

School of physical science and technology

*Corresponding author. Email: 2018302020110@whu.edu.cn

ABSTRACT

A large number of foreign studies have confirmed that the existence of female members in the board of directors will reduce the company's earnings management. This paper focuses on the Chinese market to study the impact of the female managers on the company's earnings management in this market. From the perspective of system, female social background, and the data of China's listed companies, it is confirmed that female managers tend to increase the company's earnings management. With the increasing proportion of female managers in the Chinese market, this phenomenon is becoming more and more obvious. This paper makes a detailed analysis on the institutional analysis of Chinese market and the impact of social background on female managers.
\end{abstract}

Keywords: female board of directors, earnings management, Chinese market

\section{INTRODUCTION}

Earnings management can be considered as the behavior that the company's management chooses to intervene in the company's financial report in order to achieve certain purpose. Among many factors that affect the company's earnings management, we choose to mainly study the influence of gender diversity on the company's earnings management, woman's moral concepts, ways of doing things, interpersonal relations, and many other aspects which are very different from men.

The differences in values among board members due to gender diversity usually improve the quality of board decision-making. This is because that decision-making needs to consider more diverse demands. Such differences are less obvious in areas where the equal rights movement between men and women is better. For some developing countries, men and women usually do not achieve full equal rights, so that such inequality is more serious. It improves the decision-making quality of the board of directors with gender diversity.[1]. It can be concluded that in areas where there is a greater difference in the rights of men and women.[2], the education level and personal quality of women who need to be on the board of directors are often higher than those of the rest of the male members on the board of directors. [1] Without considering social responsibility and decisiveness in decision-making, the comprehensive quality of female members on the board of directors is generally better than that of men. [2]

The influence of female members on the earnings management can be divided into three groups: upward influence, downward influence, and the inverted Ushaped relationship between female members and the earnings management.[3] Based on the study of the developed capital market, female CFOs usually prefer downward earnings management [3] because the general idea is that women are more conservative, the overall quality is higher, and they are not inclined to increase earnings management. [4] However, through data collation and statistics in the literature, it is shown that there is a positive relationship between the existence of female members and the earnings management in the constructed model. The existence of female members in the board of directors often improves the company's earnings management.

The impact of gender diversity on the earnings management quality also needs to consider the impact of gender on corporate social responsibility and legal awareness. Compared with the developed capital market [5], in the Chinese market, the board of directors with female members shows an increasing trend in the company's earnings management, which involves a variety of possible reasons. [5]. For example, the personality characteristics of female managers in China 
may be different from our traditional ideas, and female managers in the Chinese market may, to some extent, have more values than male managers. In order to confirm this view, our paper will contribute to the existing literature from the following aspects.

In China's social environment, there are differences in the rights of men and women in different local customs [6]. In China's society, especially in highly developed areas, the equal rights movement between men and women has been well developed. However, based on the traditional concept that men are superior to women, women still hace disadvantages in many social opinions and communication concepts [6], which also reflects the lack of leadership in the workplace. The proportion of women is far lower than that of men, and women take on more family responsibilities, while for career management, mostly are men [6]

For the research of gender on the level of earnings management, foreign research mainly shows that female executives prefer downward earnings management, which is mainly based on women's higher moral standards and low risk preference. However, the same research shows that the regional culture of listed companies still has a significant impact on the earnings management. And for Chinese companies listed overseas, the system is also more biased to the management system of overseas countries. For the Chinese market, the data shows that female executives have more influence on earnings management.

This paper holds the view that in the listed companies in China, gender diversity at the executive level will increase the company's earnings management, and according to whether the company is a state-owned enterprise and whether it is examined by the big four, there are differences in the significance of gender diversity for the increase of earnings management.[8]

Firstly, verify the positive correlation between the gender diversity and the earnings management. Our empirical results also confirm the positive correlation between gender diversity of management and earnings management in Chinese market.

Secondly, this study also considers the impact of gender on the earnings management in the time dimension. If the existence of female managers affects the performance of a company, it also has a significant impact on the company's financial disclosure, considering the possible impact of a variety of factors on the positive correlation.

Thirdly, in order to further discuss this issue, and considering the reasons of the selected time interval, this study finally chooses the time interval of $20 x x-20 x x$ to restore a complete economic cycle in the Chinese market as long as possible. At the same time, it can be considered that China's equal rights movement is in a process of development in this period.
This paper will first compare the differences between the Chinese market environment and the western market environment to put forward the different performance of female managers in Chinese market. And then by combining with the influence of Chinese traditional society, the possible impact of female executives on the earnings management is put forward. Combined with data analysis, this paper establishes a model to confirm that female managers prefer to increase earnings management in Chinese market. Finally, it further analyzes the impact of whether the company belongs to the state-owned enterprises and whether the company is audited by the big four.

\section{HYPOTHETICAL DEVELOPMENT}

In fact, considering the influence of female board secretaries on earnings management, it is based on the personality and psychological analysis of female board secretaries, women's impression of company information, and their aversion to risks, so as to enhance the supervision of all kinds of company information [9] Most companies in China are carrying out a "women rise" campaign, and female board secretaries are becoming more and more popular. However, based on the actual situation of the Chinese market, it is true that when the number of female directors and secretaries gradually increases, the overall company's earnings management shows an upward trend, and the existence of female directors and secretaries does not improve the quality of information disclosure of the company as expected [9] In addition, [9] after considering the proportion of female CEOs, CFOs and other senior management positions of large listed companies, the above-mentioned situation is not perfect. The phenomenon still exists that female board members have not improved the quality of information disclosure and earnings management.

Theoretically, the emergence of female board members makes the board of directors more comprehensive, and the board of directors should play a high role in improving the governance level of listed companies. A large number of studies have shown that the quality of corporate information disclosure has a significant impact on the efficiency of the whole financial market, and the quality of corporate information disclosure comes from whether directors can give full play to their duties, Female secretaries mean that their way of doing things is different from that of male secretaries, which leads to the deviation of earnings management and information disclosure quality. [10]

For female secretaries, there are three kinds of influence on company performance: 1) positive influence, 2) negative influence and 3) no significant influence. In addition to the differences in personality, female and male secretaries also show differences in 
many characteristics, such as sense of responsibility, leadership style, and communication ability. [11] Previous studies suggest that women prefer risk aversion, so the quality of information disclosure will be improved. But in fact, the opposite result is reflected in the Chinese market [11]. Whether female directors and secretaries can fulfill their duties according to the expected personality characteristics will also be affected by China's social environment and social culture. In the traditional view, women are still a family role rather than a social role.

Therefore, generally speaking, women's involvement in work is lower than men's, and in the company's management environment, men's role is more important Sex is still more competitive and has a say than women's. In the high-intensity competition of the management, women are likely to show low efficiency in their work. [12] At the same time, in order to compete in management, women are likely to endow themselves with male characteristics. [13] The addition of women's roles may also further deepen the differences in the decision-making of the management, so it has a negative impact on the management It improves the overall decision-making efficiency of the company. [14] The low efficiency of the company will be reflected in the decrease of the quality of information disclosure and the increase of earnings management.

Based on the above analysis, this paper puts forward the hypothesis.

H1a:In the Chinese market, the existence of female executives will increase the company's earnings management.

\section{RESEARCH DESIGN}

\subsection{Construction of samples}

Our sample includes 7314 listed companies from China from 2010 to 2017, among which 5108 companies have female board members, and 2206 companies have no female board members. The data in this paper are from CSMAR and Oriental Fortune. The choice of year is to restore an economic cycle as completely as possible. The missing values of the main variables are eliminated. In order to reduce the impact of outliers, a $1 \%$ tail reduction is carried out for the data.

\subsection{Model}

At first, this paper chooses to study the influence of the proportion of female board members on earnings management, but it always shows the principle of low significance. Finally, we study the influence of whether there are female board members on earnings management. The basic model selected in this paper is multiple regression equation, which is based on one variable regression equation:

$$
\begin{gathered}
E M_{i, t+1}=\beta_{0}+\beta_{1} * G D_{i, t} \quad(\text { gender diversity) } \\
+\sum_{k} y k \text { Control }_{k, i, t}
\end{gathered}
$$

In the multi-year, multi-company panel data, we mainly study the impact from time dimension and company dimension. Where $\beta \mathrm{I}$ is the regression coefficient and $\varepsilon$ is the error term. Finally, it shows that the appearance of female board members tends to increase the company's earnings management. The purpose of this study is to test whether female board members increase earnings management.

\subsection{Variables}

\subsubsection{Dependent variable}

$$
\begin{aligned}
& \frac{T_{i, t}}{\text { Assets }_{i, t-1}}= \\
& \boldsymbol{k}_{1} \frac{1}{\text { Assets }_{i, t-1}}+k_{2} \frac{\triangle \text { SALES }_{i, t}}{\text { Assets }_{i, t-1}}+k_{3} \frac{\text { PPE }_{i, t}}{\text { Assets }_{i, t-1}}+\varepsilon \\
& N A_{i, t}=k_{1} \frac{1}{\text { Assets }_{i, t-1}}+ \\
& k_{12} \frac{\triangle \text { SALES }_{i, t}}{\text { Assets }_{i, t-1}}+k_{3} \frac{P P E_{i, t}}{\text { Assets }_{i, t-1}}
\end{aligned}
$$

$$
\begin{aligned}
& A b s D A= \\
& \operatorname{Abs}\left(D A_{t-1}\right)+A b s\left(D A_{t-2}\right)+A b s\left(D A_{t-3}\right) \\
& \ln \left|\frac{\triangle P_{i, d, t}}{P_{i, d-1, t}}\right|=\alpha+\beta_{i, t}\left(\operatorname{Vol}_{\mathrm{i}, \mathrm{d}, \mathrm{t}}-\operatorname{Vol}_{\mathrm{i}, \mathrm{t}}+\mu_{\mathrm{i}, \mathrm{t}}\right.
\end{aligned}
$$

Among the dependent variables, we mainly consider the time dimension and the company's individual dimension. In the face of unpredictable risks, such as financial turmoil, the company may show a different style in a specific period of time. For the same company, due to different years, such as government policies, financial crisis, unobservable variables will have a significant impact on the company's earnings management, so we introduce the year fixed effect. Similarly, in the same year, the interaction between companies will also have a huge impact, so we introduce the individual fixed effect, which may come from the public sector The unobservable variables between departments may also come from the interaction between different industries.

\subsubsection{Test variables}

The test variable of this study is whether the board of directors includes female members. 


\subsubsection{Control variables}

Some factors, including the size of the company, the book to market ratio of the company, the company's earnings, the company's leverage, and so on, have been confirmed in many studies to have a significant impact on the company's earnings management.

\section{EXPERIENCE ANALYSIS}

\subsection{Descriptive statistics}

Table 1 shows the descriptive statistics of the variables used in our analysis. From table 1, in the sample of 7314 companies, the mean value, standard deviation, and other relevant data of different influencing factors are given. The information in the table shows that the mean value of earnings management is close to the standard deviation, which can show that the data are quite different and unevenly distributed; whether the board of directors contains women also show a big difference, and nearly $70 \%$ of the company's board of directors contain women; while the logarithm of the market value of all listed companies in the sample shows a small difference; similarly, the size of the company's board of directors also shows a big difference It also shows a small difference; the rest of the data maintain a great difference, and the average value is very close to the standard deviation.

Table 1 Statistical description table of all variables

\begin{tabular}{|l|c|c|c|c|c|c|}
\hline variable & $\mathrm{N}$ & mean & $\mathrm{sd}$ & $\min$ & $\mathrm{p} 50$ & $\max$ \\
\hline AbsDa & 7314 & 0.065 & 0.037 & 0.019 & 0.056 & 0.146 \\
\hline Female & 7314 & 0.698 & 0.459 & 0 & 1 & 1 \\
\hline Size & 7314 & 22.95 & 1.044 & 20.58 & 22.80 & 26.19 \\
\hline Tobin Q & 7314 & 2.298 & 1.312 & 0.916 & 1.890 & 7.236 \\
\hline Bm & 7314 & 0.550 & 0.236 & 0.138 & 0.529 & 1.092 \\
\hline Roa & 7314 & 0.0400 & 0.0500 & -0.164 & 0.0360 & 0.190 \\
\hline Lev & 7314 & 0.431 & 0.198 & 0.0440 & 0.425 & 0.840 \\
\hline Board & 7314 & 2.151 & 0.203 & 1.609 & 2.197 & 2.708 \\
\hline
\end{tabular}

Table 2 shows the relationship between different variables and explanatory variables. This study focuses on whether there is a relationship between female members and the company's earnings management. The Bold data in the table shows that there is a real correlation between female members and the company's earnings management. It can be explained that the existence of women in the board of directors will increase the company's earnings management, and the table is also given The correlation between other control variables was found.

Table 2 Correlation coefficient

\begin{tabular}{|c|c|c|c|c|c|c|c|c|}
\hline & $\mathrm{AbsDa}$ & Female & Size & Tobin Q & $\mathrm{Bm}$ & Roa & Lev & Board \\
\hline AbsDa & & 0.019* & $-0.034 * * *$ & $0.035^{* * *}$ & $-0.035 * * *$ & -0.015 & $0.088 * * *$ & $-0.063 * * *$ \\
\hline Female_b & $0.021 *$ & & $-0.089 * * *$ & $0.084 * * *$ & $-0.084 * * *$ & $0.024 * *$ & $-0.080 * * *$ & $-0.035 * * *$ \\
\hline Size & $-0.039 * * *$ & $-0.115 * * *$ & & $-0.213 * * *$ & $0.213 * * *$ & $0.117 * * *$ & $0.357 * * *$ & $0.181 * * *$ \\
\hline Tobin Q & $0.029 * *$ & $0.060 * * *$ & $-0.135^{* * *}$ & & $-1.000 * * *$ & $0.311 * * *$ & $-0.495 * * *$ & $-0.209 * * *$ \\
\hline $\mathrm{Bm}$ & $-0.024 * *$ & $-0.088 * * *$ & $0.298 * * *$ & $-0.852 * * *$ & & $-0.311 * * *$ & $0.495 * * *$ & $0.209 * * *$ \\
\hline Roa & -0.012 & $0.036 * * *$ & $0.131 * * *$ & $0.235 * * *$ & $-0.260 * * *$ & & $-0.380 * * *$ & $0.031 * * *$ \\
\hline Lev & $0.106^{* * *}$ & $-0.083 * * *$ & $0.370 * * *$ & $-0.418 * * *$ & $0.503 * * *$ & $-0.348 * * *$ & & $0.170 * * *$ \\
\hline Board & $-0.057 * * *$ & $-0.032 * * *$ & $0.209 * * *$ & $-0.195 * * *$ & $0.223 * * *$ & $0.033 * * *$ & $0.170 * * *$ & \\
\hline
\end{tabular}




\subsection{Single factor analysis}

In the single factor regression analysis, we divide all 7314 companies into two groups according to whether they have female board members or not. Among them, G1 has no female board members, while G2 has female board members. Among them, G1 has 2206 companies. Through the average value analysis, we can see that G2 companies have a higher average value of earnings management, It is proved that female board members affect the significant level of earnings management, so female executives do increase the company's earnings management. The table also shows that when there are female executives, the average size of the company decreases, which may still be due to the low-risk preference of high-end women.

Table 3 Single variable statistical description table

\begin{tabular}{|l|c|c|c|c|c|c|}
\hline Two-sample & $\mathrm{t}$ & test & with & equal & variances & \\
\hline Variables & G1 $(0)$ & Mean1 & G2(1) & Mean2 & MeanDiff & t-Value \\
\hline AbsDa & 2206 & 0.0630 & 5108 & 0.0650 & -0.00200 & $-1.820^{*}$ \\
\hline Size & 2206 & 23.14 & 5108 & 22.88 & 0.262 & $9.908^{* * *}$ \\
\hline Tobin Q & 2206 & 2.178 & 5108 & 2.350 & -0.172 & $-5.143^{* * *}$ \\
\hline Bm & 2206 & 0.581 & 5108 & 0.536 & 0.0450 & $7.516^{* * *}$ \\
\hline Roa & 2206 & 0.0370 & 5108 & 0.0410 & -0.00400 & $-3.088^{* * *}$ \\
\hline Lev & 2206 & 0.456 & 5108 & 0.420 & 0.0360 & $7.118^{* * *}$ \\
\hline Board & 2206 & 2.161 & 5108 & 2.147 & 0.0140 & $2.768^{* * *}$ \\
\hline
\end{tabular}

\section{REGRESSION ANALYSIS}

\subsection{Baseline regression results}

Considering the possible multicollinearity among multiple variables, which may lead to the decrease of the credibility of the results, when the final multicollinearity test for multiple variables is conducted in this study, the mean value of Vif is 2 , the maximum value is 4.4 , and all values are less than 10 , so it can be proved that there is no multicollinearity among multiple variables.

However, the univariate regression part, leaving aside the other variables temporarily, only studies the impact of the gender composition of the board of directors on the company's earnings management. The regression coefficient of gender is 0.002 , $t$ value analysis is $2.4, \mathrm{P}$ value is 0.013 , and its significance level is more than 5\%. Therefore, it shows that the regression coefficient of gender diversity is 0.002 when the explained variable is the level of earnings management At the significance level of 5\%, the regression coefficient is positive. According to the univariate regression results, it shows that gender diversity increases earnings management. After adding all the control variables, according to the regression results, the regression coefficient of the impact of gender on earnings management is 0.0025 , showing a strong significance level, indicating that at the $1 \%$ significance level, in the multiple regression equation, considering the influence of a variety of variables, the results show that female board members have a positive impact on the increase of earnings management.

\subsection{Impact}

Due to the error of the remaining variables, we can add the past earnings management as an explanatory variable, and study its impact on the current earnings management through the research on the level of surplus management.

Table 4 Benchmark regression table

\begin{tabular}{|c|c|c|}
\hline VARIABLES & EM & EM \\
\hline Female & $0.002 * *$ & $0.003 * * *$ \\
\hline Size & $(2.479)$ & $(2.608)$ \\
\hline & & -0.001 \\
\hline Tobin Q & & $(-0.737)$ \\
\hline Bm & & -0.001 \\
\hline Roa & & $(-0.935)$ \\
\hline & & $(-0.008 * *$ \\
\hline & & $0.043 * *$ \\
\hline
\end{tabular}




\begin{tabular}{|c|c|c|}
\hline & & $(4.439)$ \\
\hline Lev & & $0.018^{* * *}$ \\
\hline Board & & $(5.155)$ \\
\hline year fixed effects & yes & $-0.006^{* *}$ \\
\hline industry fixed effects & yes & yes \\
\hline observation & 7314 & 7314 \\
\hline
\end{tabular}

*Indicates significance at the $10 \%$ level (two-tailed).

* Indicates significance at the 5\% level (two-tailed).

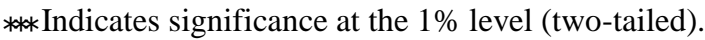

It shows that the level of earnings management in the past has a significant impact on the current level of earnings management. For the previous level of earnings, management has a significant impact on the company's current earnings management, this table gives the statistical data of each variable after referring to the previous level of earnings management. Compared with the previous chart, it can be found that after adding the lag item of earnings management, the significant level of variable diversity decreases.

Table 5 Robustness check

\begin{tabular}{|c|c|c|}
\hline VARIABLES & EM & EM \\
\hline Female & $0.003^{* * *}$ & $0.002^{*}$ \\
\hline & $(2.608)$ & $(1.817)$ \\
\hline Size & -0.001 & $-0.001 * *$ \\
\hline & $(-0.737)$ & $(-2.056)$ \\
\hline Tobin Q & -0.001 & 0.001 \\
\hline Bm & $(-0.935)$ & $(1.215)$ \\
\hline & $-0.008^{* *}$ & -0.006 \\
\hline
\end{tabular}

\begin{tabular}{|c|c|c|}
\hline & $(-2.090)$ & $(-1.360)$ \\
\hline Roa & $0.043^{* * *}$ & $0.026^{* *}$ \\
\hline Lev & $(4.439)$ & $(2.385)$ \\
\hline Board & $0.018^{* * *}$ & $0.021^{* * *}$ \\
\hline & $(5.155)$ & $(6.623)$ \\
\hline EM & $-0.006^{* *}$ & $0.008^{* * *}$ \\
\hline & $(-2.272)$ & $(-3.284)$ \\
\hline year fixed effects & yes & $0.410^{* * *}$ \\
\hline Firm fixed effects & yes & yes \\
\hline Industry fixed effects & no & no \\
\hline
\end{tabular}

* Indicates significance at the $10 \%$ level (two-tailed). ** Indicates significance at the 5\% level (two-tailed). $* * *$ Indicates significance at the $1 \%$ level (two-tailed).

The heterogeneity analysis of this paper is based on two perspectives, one is whether the company is a stateowned enterprise or a private enterprise, and the other is whether the company is audited by the four major companies. According to the statistical table, if we want to compare the private enterprises, the gender diversity of the board of directors in the state-owned enterprises has no significant impact on earnings management, while in the private enterprises, the significance level is higher, which may be because the state-owned enterprises are more supervised by government departments; while the gender diversity of the board of directors in the private enterprises has no significant impact on earnings management The results show that the gender diversity of the board of directors of the companies that are not audited by the big four has a higher significance level for earnings management, while the companies that are audited by the big four show no significant level. This is because the big four are also subject to more social supervision.

Table 6 PSM matching

\begin{tabular}{|l|c|c|c|c|c|c|}
\hline Female & Coef & Std.Err & $\mathbf{z}$ & P > I z I & \multicolumn{2}{|c|}{ [95\%Conf.Interval } \\
\hline Size & -0.2046047 & 0.0288206 & -7.1 & 0.000. & -0.261092 & -0.1481173 \\
\hline Tobin Q & -0.0123446 & 0.0391615 & -0.32 & 0.753 & -0.0890997 & 0.0644105 \\
\hline Bm & -0.4271295 & 0.2271599 & -1.88 & 0.06 & -0.8723548 & 0.0180957 \\
\hline Roa & 1.502661 & 0.5933634 & 2.53 & 0.011 & 0.3396898 & 2.665631 \\
\hline Lev & -0.144237 & 0.1670081 & -0.86 & 0.388 & -0.4715669 & 0.1830929 \\
\hline
\end{tabular}




\begin{tabular}{|l|c|c|c|c|c|c|}
\hline Board & -0.0091182 & 0.1310465 & -0.07 & 0.945 & -0.2659646 & 0.2477282 \\
\hline Cons & 5.836051 & 0.6305419 & 9.26 & 0.000. & 4.600211 & 7.07189 \\
\hline
\end{tabular}

\begin{tabular}{|c|c|c|c|}
\hline \multicolumn{2}{|c|}{ Sample matching } & \\
\hline psmatch & \multicolumn{2}{|c|}{ ssmatch:Common } & Total \\
\hline Treatment & support & 2206 \\
\hline assignment & Off support & 2205 & 5108 \\
\hline Untreated & 1 & 5107 & 7314 \\
\hline Treated & 1 & 7312 & \\
\hline Total & 2 & & On support \\
\hline
\end{tabular}

Of the 7314 samples, 7312 were matched successfully and 2 failed.

\subsection{Single score matching}

According to whether there are female executives in companies, this study divides them into two categories. Among the control variables mentioned above, there may be incomparable differences between different companies, such as company systems, company structures, and certain systematic errors. According to the matching method of PSM, in the study of G1 and G2, we temporarily put aside the factor of whether the board members include women, and try to make them match It is consistent with other variables of the object. In this study, the final choice of PSM matching method is kernel matching. When $\mathrm{t}|1.65<\mathrm{T}| 1.96, \mathrm{P}<0.10$; when $\mathrm{t}|1.96<\mathrm{T}| 2.58, \mathrm{P}<0.05$; when $\mathrm{t} \mid 2.58, \mathrm{P}<0.01$ . After removing the variable of whether there are female executives, a linear regression test is conducted on the remaining variables. The significance of different variables can be obtained by the ATT value. The PSM test results are consistent with the experimental results.

Table 7 Heterogeneity analysis

\begin{tabular}{ccccc} 
& private & state-owned & Not audited by big four & Audited by big \\
VARIABLES & AbsDa & AbsDa & AbsDa & AbsDa \\
& $0.003^{* *}$ & 0.001 & $0.002^{* *}$ & 0.002 \\
\cline { 2 - 3 } Size & $(2.293)$ & $(0.703)$ & $(2.181)$ & $(0.505)$ \\
& $0.002^{* *}$ & -0.002 & 0.000 & -0.002 \\
Tobin Q & $(2.047)$ & $(-1.262)$ & $(0.488)$ & $(-0.541)$ \\
& -0.001 & 0.001 & -0.001 & -0.001 \\
BM & $(-1.369)$ & $(0.379)$ & $(-0.976)$ & $(-0.586)$ \\
& -0.004 & -0.008 & $-0.007 *$ & -0.006 \\
Roa & $(-0.775)$ & $(-1.012)$ & $(-1.759)$ & $(-0.365)$ \\
& $0.036 * * *$ & $0.041^{*}$ & $0.042^{* * *}$ & 0.031 \\
Lev & $(3.042)$ & $(1.855)$ & $(4.194)$ & $(0.491)$ \\
Board & $0.012^{* * *}$ & $0.024 * * *$ & $0.017 * * *$ & 0.009 \\
& $(2.831)$ & $(2.942)$ & $(4.878)$ & $(0.426)$ \\
& $-0.007 * *$ & -0.002 & $-0.007 * *$ & -0.011 \\
& $(-2.023)$ & $(-0.492)$ & $(-2.295)$ & $(-1.464)$
\end{tabular}

\section{CONCLUSION}

The gender diversity of the board of directors has a significant impact on the earnings management and information disclosure. However, due to the different systems and cultural backgrounds in various market environments, the role that women can play in corporate decision-making and the way they play will change. Through a large number of studies, we tend to think that female executives have higher moral standards, educational background, and more risk-averse personality. Therefore, many people infer that female 
executives help to reduce the company's earnings management. However, the fact about the Chinese market is that female executives tend to increase the company's earnings management. The cultural background of Chinese society makes it easier for female executives to be more bold and decisive than men. Moreover, China's social system and large companies are subject to all kinds of social and internal supervision. All of these reasons contribute to the huge difference between the influence of female executives on earnings management in Chinese large companies and that in western society. The reasons for this difference, as well as the deeper social problems that we need to think about, are worthy of more research.

Appendix

Tobin Q It refers to the ratio of the market value of capital to its replacement cost.

Size The total market value of the stock is the natural logarithm.

Female Whether there are female executives or not, the female value in this paper is 1

when there are female executives, and 0 when there are no female executives

Roa A useful indicator to evaluate the profitability of a company relative to its

total assets.

The size of the company's board of directors, including the number of directors and the integrity of the vocational Committee.

and the integrity of the vocational Committee.

$\mathrm{Bm} \quad$ Means that the average monthly return of companies with higher BM value is

higher than that of companies with lower BM value.

Lev

Leverage ratio refers to the ratio of total assets to equity capital in the

balance sheet.

\section{REFERENCES}

[1] Guping Cheng;Safdar Sial Muhammad; Wan Peng; Badulescu Alina;Badulescu Daniel; Vianna Brugni Tall-es Do Board Gender Diversity and NonExecutive Directors Affect CSR Reporting? Insight from Agency Theo-ry Perspective [J] Sustainability,2020

[2] Mehdi Nekhili;Fahim Javed;Haithem Nagati Audit Partner Gender, Leadership and Ethics: The Case of Earnings Management [J] Journal of Business
Ethics, 2021.

[3] Yahya Farzan, Abbas Ghulam, Ahmed Ammar et al. Restrictive and Supportive Mechanisms for Female Directors' Risk-Averse Behavior: Evidence From South Asian Health Care Industry[J] SAGE Open, 2020, 10(4

[4] Kwee Pheng Lim, Chun Teck Lye, Yee Yen Yuen et al. Women directors and performance: evidence from Malaysia[J] Equality, Diversity and Inclusion: An International Journal, 2019, 38(8) 
[5] Kerstin Lopatta; Katarina Böttcher; Sumit K. Lodhia; Sebastian A. Tideman The Relationship Between Gender Diversity and Employee Representation at the Board Level and NonFinancial Performance: A Cross-Country Study[J]

[6] Kofi Mintah Oware;T. Mallikarjunappa Assurance service and performance. Effect of CEO characteristics [J] Meditari Accountancy Research,2020

[7] Kofi Mintah Oware;Thathaiah Mallikarjunappa Financial performance and gender diversity. The effect of family management after a decade attempt $[\mathrm{J}]$ Society and Business Review, 2021

[8] Ayman Issa, Hong Xing Fang The impact of board gender diversity on corporate social responsibility in the Arab Gulf states[J] Gender in Management: An International Journal, 2019, 34(7)

[9] Mohammad A.A Zaid, Man Wang, Sara T.F. Abuhijleh et al. Corporate governance practices and capital structure decisions: the moderating effect of gender diversity[J] Corporate Governance: The International Journal of Business in Society, 2020, 20(5)

[10] Wilma Dunaway Bringing Commodity Chain Analysis Back to Its World-Systems Roots: Rediscovering Womens Work and Households[J] Journal of World-Systems Research, 2015, 20(1)

[11] Kofi Mintah Oware;Thathaiah Mallikarjunappa Financial performance and gender diversity. The effect of family management after a decade attempt $[\mathrm{J}]$ Society and Business Review,2021

[12] Sachiko Minamizono, Kyoko Nomura, Yuki Inoue et al. Gender Division of Labor, Burnout, and Intention to Leave Work Among Young Female Nurses in Japan: A Cross-Sectional Study[J] International Journal of Environmental Research and Public Health, 2019, 16(12)

[13] Ruey Ji Guo, Yenpao Chen, Chun Chen Lee StateDependence and Conditional Audit Policy[J] Theoretical Economics Letters, 2013, $3(5 \mathrm{~B})$

[14]Ruey Ji Guo, Yenpao Chen, Chun Chen Lee StateDependence and Conditional Audit Policy[J] Theoretical Economics Letters, 2013, 3(5B) 